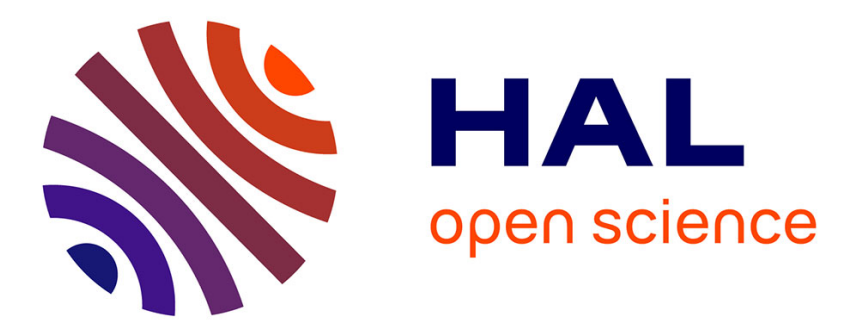

\title{
Comparison of soil seed banks of habitats distributed along an altitudinal gradient in northern Iran
}

Reza Erfanzadeh, Seyed Hamzeh Hosseini Kahnuj, Hossein Azarnivand, Julien Pétillon

\section{- To cite this version:}

Reza Erfanzadeh, Seyed Hamzeh Hosseini Kahnuj, Hossein Azarnivand, Julien Pétillon. Comparison of soil seed banks of habitats distributed along an altitudinal gradient in northern Iran. Flora, 2013, 208 (5-6), pp.312-320. 10.1016/j.flora.2013.04.004 . hal-00843479

HAL Id: hal-00843479 https://hal-univ-rennes1.archives-ouvertes.fr/hal-00843479

Submitted on 11 Jul 2013

HAL is a multi-disciplinary open access archive for the deposit and dissemination of scientific research documents, whether they are published or not. The documents may come from teaching and research institutions in France or abroad, or from public or private research centers.
L'archive ouverte pluridisciplinaire HAL, est destinée au dépôt et à la diffusion de documents scientifiques de niveau recherche, publiés ou non, émanant des établissements d'enseignement et de recherche français ou étrangers, des laboratoires publics ou privés. 


\section{Comparison of soil seed banks of habitats distributed along an altitudinal gradient in} northern Iran

\section{R. Erfanzadeh ${ }^{1, *}$, S.H. Hosseini Kahnuj ${ }^{1}$, H. Azarnivand ${ }^{2}$ and J. Pétillon $^{3}$}

\footnotetext{
${ }^{1}$ Rangeland Management Department, Faculty of Natural Resources, Tarbiat Modares University, Iran.
}

${ }^{2}$ Rangeland Management Department, Faculty of Natural Resources, Tehran University, Iran.

${ }^{3}$ URU 420 - Université de Rennes 1, UMR 7204 - Muséum National d'Histoire Naturelle, 263 Avenue du Général Leclerc, CS 74205, 35042 Rennes Cedex, France.

\footnotetext{
* Author for correspondence: Rezaerfanzadeh@modares.ac.ir
}

Tel. +98 $1226253101-3 ;+989373181169$

Fax +98 1226253499

Received 7 January 2013, accepted 30 April 2013 


\section{Abstract}

In this study we investigated the variations in soil seed banks along an altitudinal gradient in the Alborz Mountains, Iran, covering three habitats from lower to upper altitudes: forest, forest-subalpine grassland ecotone and subalpine meadow. In each habitat from 1850 to $2400 \mathrm{~m}, 20$ quadrats were established along four transects, and the above-ground vegetation and the germinable seed banks were determined. Results show that the similarity between seed bank and vegetation was lowest in the ecotone located at intermediate altitudes. Together with the contrasting highest density and species diversity of seeds at these altitudes, the ecotonal role of this habitat was confirmed.

We found evidence that lower altitudes could act as storage for seeds of some species growing at higher altitudes; the role of the ecotone was more prominent as a reserve for the meadow plant seeds than the role of the forest as a reserve for seeds of the meadow and ecotone habitats. Soil seed banks, particularly from the ecotone, can be used for restoring vegetation in some degraded sites.

(C) 2013 Elsevier GmbH

Keywords: Altitude, Density, Diversity, Forest, Subalpine meadow, Alborz Mountains

\section{Introduction}

The soil seed bank refers to seeds buried in soil that are able to remain viable for years and are potentially capable of replacing adult plants when germination requirements are met. Soil seed banks, particularly persistent ones, may function as the genetic memory of a plant population (Brown and Venable, 1986; Levin, 1990) and play an important role in community dynamics and regeneration (Bakker et al., 1996; Funes et al., 2001). The capacity of seeds to retain their viability allows species to survive episodes of disturbance and destruction (Thompson, 2000). In other words, during years when a vegetation experiences severe disturbance, buried viable seeds might reduce the danger of extinction of a population at a particular site (Bakker and Berendse, 1999).

Seed banks have high temporal (successional) and spatial variability, with conspicuous changes in density and composition (Perera, 2005; Ma et al., 2010; Erfanzadeh et al., 2010; Koch et al., 2011). Soil seed banks have vertical and horizontal distribution. The vertical distribution shows depth distribution of seeds in soil. It is well-known that depth ratios of species reflect seed longevity: seeds with higher longevity (persistent seeds) are found in deeper soil layer (Bekker et al., 1998). However, the composition of a seed bank 
depends on the above-ground vegetation (Rice, 1989) and is influenced by the surrounding vegetation (Godefroid et al. 2006). In fact, seeds can disperse into other habitats and plant communities through epizoochory and endozoochory if the habitats are being grazed (Poschlod et al. 2005; Agra and Ne'eman, 2012). Therefore it is possible that seeds produced in each habitat or community are transported to other habitats or communities and become a part of their soil seed banks (horizontal distribution). It may then be assumed that plant seeds of one habitat can be found in the soil of another habitat in spite of being absent from the above-ground vegetation of that habitat. In addition, in a single habitat (with different elevations) that has been grazed, the (re-) distribution of seeds by grazer can contribute to homogenize the spatial variation of soil seed bank among the different elevations.

Recently, studies in mountainous areas have revealed considerable seed banks in many different habitats (e.g. Ma et al., 2010; Li et al., 2012; Loydi et al., 2012; Wang et al., 2013). Although, the results showed that seed banks could be a potential source for the regeneration of some of these fragile mountainous communities, Miller and Cummins (2003) reported that mountain seed banks were so species poor that any resulting plant community would be unlikely to resemble the original community. As a result, the prospects for recovery were poor in these habitats and it was clearly preferable to minimise or avoid vegetation damage. However, most of these studies on soil seed banks focused on a single plant community in one particular habitat. Few studies actually made comparisons between and among different communities or habitats within a single geographical area.

Hence, future plans and decisions for restoration of degraded sites require more information on potential capacities of soil seed banks. In this study we investigated the variations in soil seed banks along an altitudinal gradient, covering three habitats from lower to upper altitudes: forest, forest-subalpine meadow (hereafter called ecotone) and subalpine meadow (hereafter called meadow). More precisely, we set out to test the following hypotheses: 1) soil seed bank density and diversity is constant along an altitudinal gradient in each habitat, 2) soil seed bank density and diversity will be higher in the ecotone habitat compared to a higher altitude meadow habitat or lower altitude forest habitat and 3) the similarity between the soil seed bank and above-ground vegetation will be generally low in all habitats and altitudes. We also expected to find the seeds of some species of one habitat in the soil of another habitat. Finally, we investigated to what extent the seed banks at two different soil depths were correlated to the above-ground vegetation. 


\section{Materials and methods}

\section{Description of the study area}

This study was carried out in the Vaz watershed, within the Alborz mountain chain (Iran, Fig.1). Two main domains were recognizable along the altitudinal gradient: the Hyrcanian temperate forest from 1500 to $2100 \mathrm{~m}$ a.s.l. and (subalpine) meadows which started at $2200 \mathrm{~m}$ a.s.1. towards the highest altitudes (max. altitude: $2550 \mathrm{~m}$ a.s.1.). According to the physiognomy and structure of the vegetation, it was also possible to distinguish the ecotone between the forest and meadow habitats in the forest-meadow boundary. Dominant plant species in the forest habitat were Fagus orientalis (Carpino-Fagetum orientalis community: Esmailzadeh et al. 2011) with a rich cover of herbaceous species in the understory, most prominent, among others, Asperula stellina and Brachypodium pinnatum. In meadow and ecotone habitats herbaceous species communities prevailed (Table 1). All three habitats have been grazed for many years by sheep (mostly in the meadow: five sheep per hectare) and cattle (mostly in the forest: the number of cattle per hectare is unknown). In some parts of the meadow, intensive grazing has created gaps in the vegetation, indicating the need to plan for vegetation and plant species restoration. One $\mathrm{N}-\mathrm{W}$ facing mountainside, which harboured forest, ecotone and meadow, was selected for the study. The hillside had a slope of about $80 \%$ and was part of the Vaz watershed and extended between latitudes $52^{\circ} 11^{\prime} 48.28^{\prime \prime} \mathrm{N}$ and $52^{\circ} 09^{\prime} 36.39^{\prime \prime} \mathrm{N}$ and longitudes $36^{\circ} 16^{\prime} 16.19^{\prime \prime} \mathrm{E}$ and 36 $17^{\prime} 10.711^{\prime \prime} \mathrm{E}$ (Fig. $1)$.

\section{$\ll<$ Fig. 1 (width of page; $C \mathcal{O} L \mathcal{O}$ author question!)}

\section{Seed bank sampling}

In each habitat (forest, ecotone and meadow) a key area was selected with a ca. 5 ha surface. The key area was a homogenous area which could be considered to be representative of the entire habitat in that location (Heady and Child, 1994). In each area, four transects, $100 \mathrm{~m}$ long, were established perpendicular to the main gradient (slope) with a 50m altitudinal difference between two transects (distances between two adjacent transects could therefore be different). GPS was used to determine the location and altitude of each transect. Along each transect, five $2 \mathrm{~m} \times 2 \mathrm{~m}$ quadrats were systematically established. Soil samples were collected in March 2010 when natural stratification had already taken place in the field and the soil seed bank combined transient as well as persistent seed banks. Nevertheless, the samples were stored moist at $3-4{ }^{\circ} \mathrm{C}$ for two months in the laboratory to cold stratify the seeds and to treat dormancy breaking (Allen and Nowak, 2008; Schwienbacher et al., 2011). Using a $3 \mathrm{~cm}$ 
diameter auger, 25 soil cores were collected randomly to a depth of $10 \mathrm{~cm}$ from each quadrat. These samples were divided into two subsamples $(0-5$ and 5-10 cm), and the subsamples were then pooled per soil layer for each quadrat. This resulted in an average of about 0.88 litre of soil sample from each quadrat for each layer, which exceeded the recommended 0.80 litre of soil necessary to determine the species composition of the seed bank (Hutchings, 1986). After cold treatment, the subsamples were then spread-out in a thin layer $(4 \mathrm{~mm})$ in $40 \mathrm{~cm} \times 36 \mathrm{~cm}$ trays filled with sterilized potting soil. Therefore, for each transect, 10 trays were assigned: 5 for the upper layer and 5 for the lower layer. The trays were placed randomly on shelves in a greenhouse with a natural light regime and were kept moist by spraying regularly with tap water. 15 control trays, filled with the same sterilized potting soil were also placed randomly on the shelves to test for possible greenhouse and potting soil contamination.

Seedlings were identified as soon as possible after germination, counted and removed or, if they could not be identified immediately, were transplanted into pots to allow further growth and identification.

After 7 months, when there was no further seed germination, the trays were left to dry for two weeks. This allowed the samples to be crumbled to expose deeper buried seeds to the light. After watering the samples for another two weeks, no new seedlings emerged. Nevertheless, the residual soil was checked for remaining seeds by viewing small random samples taken from the trays under a microscope and probing seeds with a needle in order to distinguish between firm and empty seeds. Since the number of seeds that remained in the investigated soil samples was very low, we did not correct germination data for remaining viable seeds.

\section{Vegetation sampling}

Above-ground vegetation was recorded during the growing season of each habitat in 2011 by visually estimating the cover of all vascular plant species using a decimal scale (Londo, 1976) in all quadrats used for the soil seed bank sampling. In the forest and ecotone habitats, the percentage cover of shrubs and trees was also recorded in the same quadrats.

\section{Data analysis}

Seedling counts were recalculated to germinable seed density, expressed per $\mathrm{m}^{2}$ for each $5 \mathrm{~cm}$ soil depth layer and for each species separately. Similarity between the species 
composition of the above-ground vegetation and the soil seed bank was assessed using the qualitative Sørensen similarity index (Kent and Coker, 1995) in each quadrat for each depth separately. In addition, in each quadrat, species diversity of the seed bank was calculated using a Shannon index for each soil layer separately (Kent and Coker, 1995).

Seed density was transformed to $\log 10(\mathrm{X}+1)$ to meet normal distribution. A general linear model was used to compare the seed density, diversity and similarity between altitudes. Seed bank characteristics were introduced as dependent variables, while depth categories (0$5 \mathrm{~cm}$ and $5-10 \mathrm{~cm}$ ) and altitude categories (twelve different altitudes) were introduced as fixed factors. An interaction between depth and altitude was also considered in the model. Furthermore, the data were divided into three groups: forest, ecotone and meadow. Seed bank characteristics were introduced as dependent variables, and depth and habitat as fixed factors. Interactions between fixed factors were also entered into the model (see also Erfanzadeh et al. 2010). These statistical analyses were performed using SPSS 16 (SPSS Inc, USA; www.spss.com).

To compare the composition and abundance of species in the vegetation and the seed banks in the three habitats, a multivariate ordination was conducted using Detrended Correspondence Analysis (DCA; Hill and Gauch, 1980). DCA was used to examine the variation in plant species composition, and was applied to the species frequency data. Graphical plots of data ordinations were constructed using CANODRAW (Smilauer, 1992). All analyses were performed using the CANOCO program, following the default options for DCA. For both ordinations of the seed bank and vegetation data, the two first ordination axes were retained for interpretation. For seed bank data, species frequencies were calculated as the number of seedlings of one species divided by the total number of seedlings in the seed bank for each quadrat.

\section{Results}

\section{Species composition in the soil seed bank and above-ground vegetation}

In total, 92 species germinated from the soil samples: 35 species in the forest, 74 in the ecotone and 49 in the meadow. The dominant plant species were Carex sp. in the forest and ecotone and Festuca ovina in the meadow (Table 1).

$\ll<$ Tab. 1

In total, 116 species were recorded in the above-ground vegetation of which 59, 74 and 65 species were observed only in forest, ecotone and meadow habitats, respectively. The 
dominant plant species were Fagus orientalis, Brachypodium pinnatum and Festuca ovina in the forest, ecotone and meadow habitats, respectively (Table 1).

\section{The relationship between the soil seed bank and above-ground vegetation}

Similarity between the soil seed bank and above-ground vegetation was relatively low in all habitats and at different altitudes. The mean values of Sørensen similarity indices between above-ground vegetation and the seed banks of the upper soil layer were $19.6 \%$, $14.6 \%$ and $24.3 \%$ in forest, ecotone and meadow habitats, respectively. The mean values of Sørensen similarity indices between the above-ground vegetation and seed banks of the lower soil layer were $8.1 \%, 11.1 \%$ and $10.2 \%$ for forest, ecotone and meadow habitats, respectively. The results of GLM showed that depth, altitude, habitats, interactions between depth $\times$ habitat and depth $\times$ altitude had significant effects on similarity between the soil seed bank and above-ground vegetation $(\mathrm{P}<0.05)$. Similarity between the soil seed bank of the upper soil layer and above-ground vegetation was significantly lower in the ecotone than in the forest and meadow. This similarity was also significantly higher at some altitudes located in the forest and the meadow than at the altitudes located in the ecotone. Similarity between the soil seed bank of the lower layer of soil samples and above-ground vegetation was not significantly different between altitudes and habitats (Table 2).

$\ll<$ Tab. 2

Detrended correspondence analysis (DCA) of the soil seed bank and vegetation quadrats identified groupings of species composition (Fig. 2). The first axis of the DCA corresponded to the altitudinal gradient with forest habitat at the right and meadow habitat at the left side. The second axis of the DCA showed a good separation of the soil seed bank and vegetation in the ecotone ( $\mathrm{Ev}$ and Es), while there was overlap between the soil seed bank and above-ground vegetation in the forest and the meadow. The distance between the meadow $(\mathrm{Mv})$ and ecotone vegetation $(\mathrm{Ev})$ groups was greater than the distance between the ecotone $(\mathrm{Ev})$ and forest vegetation $(\mathrm{Fv})$ groups. The distances between seed banks also followed the above-ground vegetation distances. Whereas there was an overlap between soil seed banks of forest and ecotone habitats, soil seed banks of ecotone and meadow were clearly segregated.

$\ll<$ Fig. 2 (column width)

$\ll<$ Fig. $3(\sim 1 / 4$ height of page $)$

\section{Species diversity in the soil seed bank}


The species diversity of the seed bank in the upper soil layer was highest at $2050 \mathrm{~m}$ altitude (Fig. 3) and significantly higher in the ecotone than in the forest and in the meadow. Although the species diversity of the seed bank in the lower soil layer changed significantly with altitude in the three different habitats, the variation of soil seed diversity between different altitudes and habitats was relatively low and did not follow a constant variation in this soil layer (Table 2).

\section{Seed density}

Mean seed densities in upper soil layers of forest, ecotone and meadow habitats were significantly different: 2821 seeds $\mathrm{m}^{-2}, 11453$ seeds $\mathrm{m}^{-2}$ and 4390 seeds $\mathrm{m}^{-2}$, respectively, and in lower soil layers, 252 seeds $\mathrm{m}^{-2}, 473$ seeds $\mathrm{m}^{-2}$ and 583 seeds $\mathrm{m}^{-2}$, respectively. In all habitats, seed density was significantly higher in the upper than in the lower soil layers (Fig. 4). The interaction between habitat and depth was significant.

Seed density in the upper soil layers was significantly higher at altitudes of $2050 \mathrm{~m}$ and $2100 \mathrm{~m}$ than at the other altitudes. Seed density in the lower soil layer was significantly higher at $2250 \mathrm{~m}$ than at the other altitudes (Fig. 5 and Table 2).

$\ll<$ Fig. $4(\sim 1 / 4 \underline{\text { height }}$ of page $)$

$\ll<$ Fig. $5(\sim 1 / 4$ height of page $)$

\section{Discussion}

The most prominent result of this study is the important role of forest habitats as a reserve of seeds coming from ecotone and meadow habitats. Seeds of 17 species (Adonis aestivalis, Brachypodium sylvaticum, Dianthus orientalis, Galium aparine, Geranium collinum, Lactuca glaucifolia, Marubium vulgare, Prunella grandiflora, Phleum iranicum, Poa bulbosa, Sedum hispanicum, Scutellaria tournefortii, Taraxacum montanum, Thymus serpyllum and T. kotschyanus, Trifolium angustifolium and Ziziphora clinopodioides) were present in the soil inside the forest in spite of being absent in the above-ground vegetation of the forest. Several of these species were also present in the above-ground vegetation of the meadow. It is hypothesized that the seeds of these species had been produced in the meadow habitat and were then transferred into the forest habitat (probably by grazing animals; cf. Wessels-de Wit and Schwabe, 2010). Similarly, the seeds of 22 species were present in the soil of the ecotone zone while these species were present in the above-ground vegetation of the meadow and absent in the vegetation of the ecotone zone. It can thus be concluded that woody plants which exist in the forest and forest meadow habitats probably act against 
intensive grazing for the seed of herbaceous species coming from other habitats. As a result, lower altitudes and their woody vegetation could act as a store for seeds of species growing in open-land at higher altitudes or of species that had formerly existed at higher altitudes. It should be eventually possible, therefore, to rely on the forest seed bank to recover extinct species from meadows, by transporting the soil from the forest into the meadow or by extracting meadow seeds from forest soil.

\section{The relationship between the soil seed bank and above-ground vegetation}

The similarity between the seed bank and the above-ground vegetation was generally low at all altitudes and ranged from $14 \%$ to $24 \%$ for the upper soil layer and $8 \%$ to $11 \%$ for the lower soil layer. A low similarity or the lack of correspondence between the seed banks and above-ground vegetation has been reported also in other habitats, like sand dunes (Planisek and Pippen, 1984), agro-ecosystems (e.g. Caixinhas et al., 1993), grasslands (e.g. Funes et al., 2003; Koch et al., 2011), semi-arid rangeland (Solomon et al., 2006), alpine meadows (Ma et al., 2010), salt marshes (Erfanzadeh et al., 2010) and the lower ranges of the Hyrcanian forest (Esmailzadeh et al., 2011). This low similarity indicates that the contribution of the dominant species to the formation of the soil seed bank is of minor importance. In contrast, high similarity between the above-ground vegetation and the soil seed bank has been reported in few only other studies (e.g. Shaukat and Siddiqui, 2004). In the present study, the similarity between the above-ground vegetation and the seed bank of the upper layer $(0-5 \mathrm{~cm}$ depth) showed a U-shaped curve along the altitudinal gradient, where the lowest values were mostly at altitudes between 2050 and $2200 \mathrm{~m}$ a.s.l. The result of DCA also showed that the species composition of the vegetation was very different from the soil seed banks in the ecotone quadrats. The species composition in the forest and meadow habitats did not show such obvious differentiation between seed bank and vegetation.

Although, Sørensen similarity index between soil seed bank and above-ground vegetation was relatively low in all habitats, but it was lowest in the ecotone habitat. The low similarity between above-ground vegetation and soil seed bank at this habitat may be related to the fact that the above-ground vegetation at these altitudes was highly represented by species that were absent from the seed bank, such as Holosteum sp., Achillea millefolium, Agrostis sp. and

Centaurea cyanus. Some Poaceae (e.g. Agrostis sp.) are clonal species which had probably increased their vegetative growth as a form of alternative reproduction against grazing at the expense of seed production, and therefore contributed less to the seed banks. The ecotone 
seed bank included Artemisia chamaemelifolia, Brachypodium sylvaticum and Crepis kotschyana which were absent in the above-ground vegetation there. Despite a relative high cover percentage of shrubs and trees in the above-ground vegetation of forest and ecotone habitats, most of these species were absent in the soil seed bank. The portion of forbs in the seed bank was high compared to their proportion in the above-ground vegetation. All of these latter species produce numerous small seeds that are dispersed by wind, animals or even by water, and they have a high survival potential in the soil (Fenner and Thompson, 2005). In the forest, Fagus orientalis was dominant in above-ground vegetation, but neither its nutlets nor diaspores of other trees (e.g. Quercus castaneifolia and Carpinus orientalis) were ever found in the seed bank. Viable seeds of those species may not accumulate in the soil, because of a greater risk of mortality - by recalcitrance (oak acorns) as well as by predation by animals (Lambers et al., 2005), or because virtually all viable seeds germinated in the spring (Esmailzadeh et al., 2011). A previous study in the Hyrcanian forest also showed that all the species that were either recorded only in the above-ground vegetation and absent from seed bank, or abundant in the vegetation but rare in the seed bank were tress and long-lived perennials (Asadi et al., 2012). Surprisingly, Trifolium angustifolium was never found in the above-ground vegetation of the study area but found in the seed bank of all the three habitats. This species is a very palatable plant, particularly for sheep, and is therefore extremely underrepresented in the standing vegetation, enduring hidden against the grazers as seed in soil.

The similarity between the soil seed bank of the upper soil layer and the above-ground vegetation in the meadow habitat, in particular where over-grazing had degraded some parts of it, was relatively high compared with the situation in the ecotone and forest habitats (24.3\% vs. $14.6 \%$ and $19.6 \%)$. Based on these results, we conclude that in degraded meadows the potential role of the local seed bank for the restoration is relatively high. Cessation of grazing could indeed permit the restoration of degraded sites there, because bare soil gaps can be colonized with species belonging to the above-ground vegetation via the seed bank (no need of epizoochorous dispersal by sheep, as described by Wessels et al. (2008), although top-soil removal can be necessary improving the restoration success (Verhagen et al., 2001).

Since many species in the above-ground vegetation are unpalatable or less well palatable (such as Brachypodium pinnatum and Festuca ovina: Massey et al. 2009), managers are advised to think about restoration of a high-diversity grass and herb vegetation via the seed bank. If restoration of bare soil gaps by more palatable species is desired, then the introduction of their seeds from hitherto un-grazed sites would be necessary, since 
availability of the seeds of these species in the seed bank of grazed meadows is negligible or absent.

In the northwestern Red Sea region, Hegazy et al. (2009) also found that similarity between above-ground vegetation and the soil seed bank was lowest at intermediate altitudes. In contrast, Ma et al. (2010) found that similarity between the species composition of the vegetation and the seed bank decreased with increasing altitude. The investigated vegetation of both studies differs strongly from that in the Alborz Mountains. Here, the relatively greatest similarity between the floras of seed bank and standing vegetation is given in the high-altitude meadows.

Although in all habitats seed density in the lower soil layers $(5-10 \mathrm{~cm}$ depth) was generally low compared with the upper layers, it was significantly higher in the meadow than in the other two habitats. The rate of persistent seeds in the meadow seed bank is consequently higher than in the forest and ecotone. Indeed, persistent seeds are known to penetrate rather often deeper into the soil than seeds belonging to transient seed banks (Thompson et al., 1997).

\section{Seed density and diversity}

Seed density and diversity was highest at some altitude transects located in the ecotone in the upper soil layer. In fact, here often a clumping of seeds was found. These results, together with the low similarity between the soil seed bank and above-ground vegetation, underline the function of the ecotone habitat connecting different vegetation types. High diversity in the above-ground vegetation (local vegetation) and high seed density buried in the soil by few plant species in the ecotone are characteristic for this vegetation type. Seeds of some species, like Brachypodium pinnatum, Lepidium sativum and Gentiana olivieri, occurred at high numbers in this habitat while they were absent or with very low occurrence in the soil of the two other habitats.

In the ecotone habitat, the number of species in above-ground vegetation was 55, while the number of species in the upper soil layer was 56. In the other two habitats, the number of species in the soil seed bank was much lower than the number of species in the above-ground vegetation. Seeds probably enter the ecotone from surrounding areas, perhaps by sheep translocation, since this habitat is located between the forest and meadow habitats, and the animals move across the ecotone. Previous studies (e.g. Poschlod et al., 2005) reported that seeds of many species can be dispersed by epizoochory (seed dispersal on the 
body surface of mammals) and endozoochory (seed dispersal via ingestion by mammals). However, the amount of seed dispersal by grazing animal in this specific location still needs to be quantified.

The humped trend of seed bank density and diversity at the $0-5 \mathrm{~cm}$ depth along the altitude gradient demonstrated that the present study is not directly comparable with either the results obtained by Cummins and Miller (2002) and Ma et al. (2010) in which seed bank density and species richness decreased significantly with increasing altitude, or the results obtained by Funes et al. (2003) in which the richness and density of the soil seed bank increased with increasing altitude. The different outcomes of methodically similar investigations in different regions of the world point to the peculiar importance the floristically and structurally different vegetation types have.

Our study revealed that, conforming to our expectations, forest habitats contain a smaller number of seeds than meadows. However, the forest contained some seeds of species that are typical for the above-ground vegetation of species occurring in the ecotone range and at the meadows in higher altitudes of the mountain range, so that the forest belt, at least in its upper ranges, acts as a genetic memory, at least for a short period of time. This role is even more prominent for the ecotone which represents indeed a seed reserve for the meadow species. Some seeds were found at lower altitudes (forest) which are not present in the aboveground vegetation indicating that deterministic factors, rather than stochastic factors, might drive the plant communities at these altitudes. Finally, it is well-known that Asperula odorata and Brachypodium sylvaticum are typical species of deciduous forests. Surprisingly, we found these species in the above-ground vegetation of upper elevations in the meadow habitat. Whether occurrence of these species is generally shifting to higher altitudes, possibly as a consequence of a climatic warming, needs to be investigated in future studies.

\section{Acknowledgments}

We would like to acknowledge the Iranian University of Tarbiat Modares for technical and financial support. We thank Dr. H. Ghelichnia and Dr S.H. Zali for their kind help with plant identification, Dr J.P. Bakker for his valuable comments on an earlier draft, and Aldyth Nys for editing the English.

\section{References}


Agra, H., Ne'eman, G., 2012. Composition and diversity of herbaceous patches in woody vegetation: The effects of grazing, soil seed bank, patch spatial properties and scale. Flora 207, 310-317.

Allen, E.A., Nowak, R., 2008. Effect of tree cover on soil seed bank in pinyon-juniper, Pinus monophylla and Juniperus osteosperma woodland. Rangeland Ecol. Manage. 61, 63-73.

Asadi, H., Hosseini, S.M., Esmailzadeh, O., Baskin. C.C., 2012. Persistent soil seed banks in old-growth Hyrcanian Box tree (Buxux hyrcana) stands in northern Iran. Ecol. Res. 27, 23-33.

Bakker, J.P., Berendse, F., 1999. Constraints in the restoration of ecological diversity in grassland and heathland communities. Trends Ecol. Evol. 14, 63-68.

Bakker, J.P., Bakker, E.S., Rosen, E., Verweij, G.L., Bekker, R.M., 1996. Soil seed bank composition along a gradient from dry alvar grassland to Juniperus shrubland. J. Veget. Sci. 7, 165-176.

Bekker, R.M. et al. (8 authors), 1998. Seed size, shape and vertical distribution in the soil: indicators of seed longivity. Funct. Ecol. 12, 834-842.

Brown, J.S., Venable, D.L., 1986. Evolutionary ecology of seed bank annuals in temporally varying environments, Am. Nat. 127, 31-47.

Cummins R.P., Miller, G.R., 2002. Altitudinal gradients in seed dynamics of Calluna vulgaris in eastern Scotland. J. Veget. Sci. 13, 859-866.

Erfanzadeh, R., Garbutt A., Pétillon, J., Maelfait, J.-P., Hoffmann, M., 2010. Factors affecting the success of early salt-marsh colonizers: seed availability rather than site suitability and dispersal traits. Plant Ecol. 206, 335-347.

Esmailzadeh, O., Hosseini S. M., Tabari Masoud., Baskin, C.C., Asadi, H., 2011. Persistent soil seed banks and floristic diversity in Fagus orientalis forest communities in the Hyrcanian vegetation region of Iran. Flora 206, 365-372.

Fenner, M., Thompson, K., 2005. The Ecology of Seeds. Cambridge University Press, Cambridge.

Funes, G., Basconcelo, S., Díaz, S., Cabido, M., 2001. Edaphic patchiness influences grassland regeneration from the soil seed bank in mountain grassland of central Argentina. Austral Ecol. 26, 205-212.

Funes, G., Basconcelo, S., Díaz, S., Cabido, M., 2003. Seed bank dynamics in tall-tussock grasslands along an altitudinal gradient. J. Veget. Sci. 14, 253-258.

Godefroid, S., Phartyal, S.S., Koedam, N., 2006. Depth distribution and composition of seed banks under different tree layers in a managed temperate forest ecosystem. Acta Oecol. 29, 283-292.

Heady, H.F., Child, R.D., 1994. Rangeland Ecology and Management. Westview Press, Boulder, Co., USA.

Hegazy, A.K., Hammouda, O., Lovett-Doust, J., Gomaa N.H., 2009. Variations of the germinable soil seed bank along the altitudinal gradient in the northwestern Red Sea region. Acta Ecol. Sinica 29, 20-29.

Hill, M.O., Gauch, H.G., 1980. Detrended Correspondence Analysis, An Improved Ordination Technique. Wiley, Chichester, UK.

Hutchings, M.J., 1986. Plant population biology, in: P.D. Moore, P.D., Chapman, S.B. (eds.) Methods in Plant Ecology, $2^{\text {nd }}$ edit., Blackwell, Oxford, UK, pp. 377-435.

Kent, M., Coker, P., 1994. Vegetation Description and Analysis, A Practical Approach. Edinburgh University Press, Edinburgh, UK. 
Koch, M.A., Scheriau, C., Schupfner, M., Bernhardt, K.-G., 2011. Long-term monitoring of the restoration and development of limesrone grasslands in north western Germany: vegetation screening and soil seed bank analysis. Flora 206, 52-65.

Lambers, J.H.R., Clark, J.S., Lavine, M., 2005. Implication of seed banking for recruitment of southern Appalachian woody species. Ecology 86, 85-95.

Levin D., 1990. The seed bank as a source of genetic novelty in plant. Amer. Nat. 135, 563-572.

Li, Y.Y., Dong, S.K., Wen, L., Wang, X.X., Wu, Y., 2012. Soil seed banks in degraded and revegetated grasslands in the alpine region of the Qinghai-Tibetan Plateau. Ecol. Engineer. 49, 77-83.

Londo, G., 1976. The decimal scale for relevees of permanent quadrates. Vegetatio 33, 61-64.

Loydi, A., Zalba, S.M., Distel, R.A., 2012. Viable seed banks under grazing and exclosure conditions in montane mesic grasslands of Argentina. Acta Oecol. 43, 8-15.

Ma, M., Zhou, X., Du, G., 2010. Role of soil seed bank along a disturbance gradient in an alpine meadow on the tibet plateau. Flora 205, 128-134.

Massey, F.P., Messay, K., Ennos, A.R., Hartley, S.E., 2009. Impacts of silica-based defences in grasses on the feeding preferences of sheep. Basic Appl. Ecol. 7, 622-630.

Miller G.R., Cummins, R.P., 2003. Soil seed banks of woodland, heathland, grassland, mire and montane communities, Cairngorm Mountains, Scotland. Plant Ecol. 168, 255-266.

Perera, G.A.D., 2005. Spatial heterogeneity of the soil seed bank in the tropical semi-deciduous forest at Wasgomuwa National Park, Sri Lanka. Trop. Ecol. 46, 79-89.

Planisek, S.L., Pippen, R.W., 1984. Do sand dunes have seed banks? Michigan Botany 23, 169-177.

Poschlod, P., Tackenberg, O., Bonn, S., 2005. Plant dispersal potential and its relation to species frequency and coexistence. In: van der Maarel, E. (Ed.), Vegetation Ecology. John Wiley \& Sons, Hoboken, USA, pp. 147-171.

Rawlinson, H.E., 2009. An investigation into the impact of footpaths and open access land on ground flora in lower woods, gloucestershire. Earth and Environment 4, 57-82.

Rice, K.J., 1989. Impacts of seed banks on grassland community structure and population dynamics. In: Leck, M.A., Parker, V.T., Simpson, R.L. (Eds.) Ecology of Soil Seed Banks. Academic Press, San Diego, USA. pp. 212-230.

Schwienbacher, E., Navarro-Cano, J.A., Neuner, G., Erschbamer, B., 2011. Seed dormancy in alpine species. Flora 206, 845-856.

Shaukat, S.S., Siddiqui, I.A., 2004. Spatial pattern analysis of seeds of an arable soil seed bank and its relationship with above-ground vegetation in an arid region. J. Arid Environ. 57, 311-327.

Smilauer, P., 1992. CANODRAW User's guide, version 3.0. Microcomputer Power. Ithaca NY.

Solomon, T.B., Snyman, H.A., Smit, G.N., 2006. Soil seed bank characteristics in relation to land use systems and distance from water in a semi-arid rangeland of southern Ethiopia. South African J. Bot. 72, 263 271.

Thompson K., 2000. The functional ecology of soil seed banks, in: Fenner M. (Ed.) Seeds: The Ecology of Regeneration in Plant Communities, 2nd edit., CAB International Press, Wallingford, pp. 215-235.

Thompson, K., Bakker, J.P., Bekker, R.M., 1997. The Soil Seed Banks of North-West Europe: Methodology, Density and Longevity. Cambridge University Press, Cambridge. 
Verhagen, R., Klooker, J., Bakker, J.P., van Diggelen, R., 2001. Restoration success of low-production plant communities on former agricultural soils after top-soil removal. Appl. Veget. Sci. 4, 75-82.

Wang, N., Jiao, J.Y., Du, H.D., Wang, D.L., Jia, Y.F., Chen, Y., 2013. The role of local species pool, soil seed bank and seedling pool in natural vegetation restoration on abandoned slope land. Ecol. Engineer. 52, $28-36$.

Wessels, S., Eichberg, C., Storm, C., Schwabe, A., 2008. Do plant-community-based grazing regimes lead to epizoochorous dispersal of high proportions of target species? Flora 203, 304-326.

Wessels-de Wit, S., Schwabe, A., 2010. The fate of sheep-dispersed seeds: Plant species emergence and spatial patterns. Flora 205, 656-665. 
Table 1. Average seed density $\mathrm{m}^{-2}$ of species in the seed bank and cover percentage of species in the above-ground vegetation in the different habitats. Plant species are listed that had more than either 1 seed $\mathrm{m}^{-2}$ or $1 \%$ in the above-ground vegetation in at least one habitat. The digits located inside the parentheses show that the species (in the seed bank or above-ground vegetation) occurred in different altitudes, coded as follows: 1: 1850; 2:1900; 3:1950; 4:2000; 5:2050; 6:2100; 7:2150; 8:2200; 9:2250; 10:2300; 11:2350; $12: 2400 \mathrm{~m}$ a.s.l.

\begin{tabular}{|c|c|c|c|c|c|c|c|c|c|}
\hline \multirow{3}{*}{ Plant species } & \multicolumn{3}{|c|}{$\begin{array}{c}\text { Average of plant cover percentage of } \\
\text { species }\end{array}$} & \multicolumn{6}{|c|}{ Average of seed density $\mathrm{m}^{-2}$ of species } \\
\hline & \multirow[b]{2}{*}{ Forest } & \multirow[b]{2}{*}{ Ecotone } & \multirow[b]{2}{*}{ Meadow } & \multicolumn{2}{|c|}{ Forest } & \multicolumn{2}{|c|}{ Ecotone } & \multicolumn{2}{|c|}{ Meadow } \\
\hline & & & & $\begin{array}{l}0-5 \mathrm{~cm} \\
\text { soil layer }\end{array}$ & $\begin{array}{l}5-10 \\
\text { soil ayer }\end{array}$ & $\begin{array}{l}0-5 \mathrm{~cm} \\
\text { soil layer }\end{array}$ & $\begin{array}{l}0-10 \mathrm{~cm} \\
\text { soil layer }\end{array}$ & $\begin{array}{l}0-5 \mathrm{~cm} \\
\text { soil layer }\end{array}$ & $\begin{array}{l}0-10 \mathrm{~cm} \\
\text { soil layer }\end{array}$ \\
\hline Achillea millefolium L. subsp. millefolium & 0.0 & $3.0(5,6,7,8)$ & 0.0 & 0.0 & 0.0 & 0.0 & 0.0 & 0.0 & 0.0 \\
\hline Achillea wilhelmsii Boiss. & 0.0 & 0.0 & 0.0 & 0.0 & 0.0 & $98.6(7,8)$ & 0.0 & $\begin{array}{l}28.3 \\
\quad(9,10,11)\end{array}$ & 0.0 \\
\hline Acantholimon erinaceum Boiss. & 0.0 & 0.0 & 0.0 & 0.0 & 0.0 & 102.3 & 0.0 & 0.0 & 134.8 \\
\hline Adonis aestivalis Boiss. & 0.0 & 0.0 & $0.3(9,11)$ & $31.6(1,3)$ & 0.0 & $54.5(5)$ & 0.0 & $85.0(10,12)$ & $\begin{array}{l}110.2 \\
(10,11,12)\end{array}$ \\
\hline Agrostis sp. & 0.0 & $1.2(7,8)$ & 0.0 & 0.0 & 0.0 & 0.0 & 0.0 & 0.0 & 0.0 \\
\hline Alyssum minus (L.) Rothm. & $0.4(3,4)$ & $1.3(5,6,7,8)$ & $1.1(9,12)$ & 0.0 & 0.0 & $48.6(7)$ & 0.0 & 0.0 & $\begin{array}{l}46.3 \\
(10,11,12)\end{array}$ \\
\hline Arabis rimarum $\mathrm{L}$. & $1.1(3)$ & $0.1(7)$ & $0.0(9,10,11)$ & 0.0 & 0.0 & 0.00 & 0.0 & 0.0 & 0.0 \\
\hline Artemisia chamaemelifolia Boiss. & 0.0 & 0.0 & $0.1(10)$ & 0.0 & 0.0 & $114.1(5,6)$ & 0.0 & 0.0 & 0.0 \\
\hline Asperula odorata $\mathrm{L}$. & 0.0 & $1.4(8)$ & $\begin{array}{l}5.0 \\
(9,10,11,12)\end{array}$ & 0.0 & 0.0 & $52.0(6)$ & $14.7(6,7)$ & 0.0 & 0.0 \\
\hline Astragalus gossypinus Boiss. & 0.0 & 0.0 & $0.4(11,12)$ & 0.0 & 0.0 & 0.0 & 0.0 & $\begin{array}{l}486.4 \\
(9,10,11)\end{array}$ & 0.0 \\
\hline Alchemilla vulgaris $\mathrm{L}$. & $2.2(1,2,3,4)$ & 0.0 & 0.00 & 0.0 & 0.0 & 0.0 & 0.0 & 0.0 & 0.0 \\
\hline Asperula stellina $\mathrm{L}$. & $3.7(1,2,3,4)$ & 0.0 & 0.00 & 0.0 & 0.0 & 0.0 & 0.0 & 0.0 & 0.0 \\
\hline Berberis integerrima Bung. & $2.4(1,2,3,4)$ & $2.7(5,6,7)$ & 0.00 & 0.0 & 0.0 & 0.0 & 0.0 & 0.0 & 0.0 \\
\hline Brachypodium pinnatum(L.) P. Beauv. & $4.9(1,2,3)$ & $8.5(5,6,7,8)$ & $\begin{array}{l}8.2 \\
(9,10,11,12)\end{array}$ & 0.0 & 0.0 & $386.3(6,7,8)$ & 0.0 & 0.0 & 0.0 \\
\hline $\begin{array}{l}\text { Brachypodium sylvaticum (Hudson) P. } \\
\text { Beauv. }\end{array}$ & 0.0 & 0.0 & $5.0(10,12)$ & $294.2(4)$ & 0.0 & $49.4(5,6,7)$ & 0.0 & 0.0 & 0.0 \\
\hline Bromus brizoides Lam. & 0.0 & 0.0 & 0.0 & 0.0 & 0.0 & 0.0 & 0.0 & 0.0 & $\begin{array}{l}201.5 \\
(9,11,12)\end{array}$ \\
\hline Bromus tectorum $\mathrm{L}$. & 0.0 & 0.0 & 0.0 & 0.0 & 0.0 & $24.3(8)$ & 0.0 & 0.0 & 0.0 \\
\hline Bromus tomentellus Boiss. & $0.5(4)$ & $0.1(6)$ & $0.3(10,11,12)$ & 0.0 & 0.0 & $134.2(6,7)$ & 0.0 & 0.0 & 0.0 \\
\hline Carex sp. & $1.2(1)$ & $2.0(5,6,7,8)$ & 0.0 & $\begin{array}{l}1235.7 \\
(1,2,3,4)\end{array}$ & 0.0 & $\begin{array}{l}1624.1 \\
(4,6,7,8)\end{array}$ & 0.0 & 0.0 & 0.0 \\
\hline Carpinus orientalis Mill. & $1.3(1,3)$ & 0.0 & 0.0 & 0.0 & 0.0 & 0.0 & 0.0 & 0.0 & 0.0 \\
\hline Centaurea cyanus L. & $0.2(3,4)$ & $3.4(5,6,8)$ & 0.0 & 0.0 & 0.0 & 0.0 & 0.0 & 0.0 & 0.0 \\
\hline Chenopodium album $\mathrm{L}$. & $0.2(3,4)$ & $0.7(5,7)$ & 0.0 & 0.0 & 0.0 & $19.2(7)$ & 0.0 & 0.0 & $\begin{array}{l}741.7 \\
(10,11,12)\end{array}$ \\
\hline Cirsium arvense (L.) Scop. var. arvense & 0.0 & 0.0 & $0.1(10)$ & 0.0 & 0.0 & $12.4(8)$ & 0.0 & 0.0 & $146.2(12)$ \\
\hline Cousinia commutata (Boiss.)Boiss. & $0.3(1,2,3.4)$ & $0.3(5,8)$ & $0.3(10,11)$ & 0.0 & 0.0 & $32.7(4,6)$ & $42.1(8)$ & 0.0 & $\begin{array}{l}412.3 \\
(9,10)\end{array}$ \\
\hline Crepis kotschyana (Boiss.)Boiss. & 0.0 & 0.0 & $0.2(9)$ & 0.0 & 0.0 & $28.3(5,7,8)$ & 0.0 & 0.0 & 0.0 \\
\hline Cynodon dactylon (L.) Pers. & 0.0 & 0.0 & $1.3(9,10)$ & 0.0 & 0.0 & 0.0 & 0.0 & 0.0 & 0.0 \\
\hline Crataegus oxyacantha $\mathrm{L}$. & 0.0 & $1.8(6,7)$ & 0.00 & 0.0 & 0.0 & 0.0 & 0.0 & 0.0 & 0.0 \\
\hline
\end{tabular}




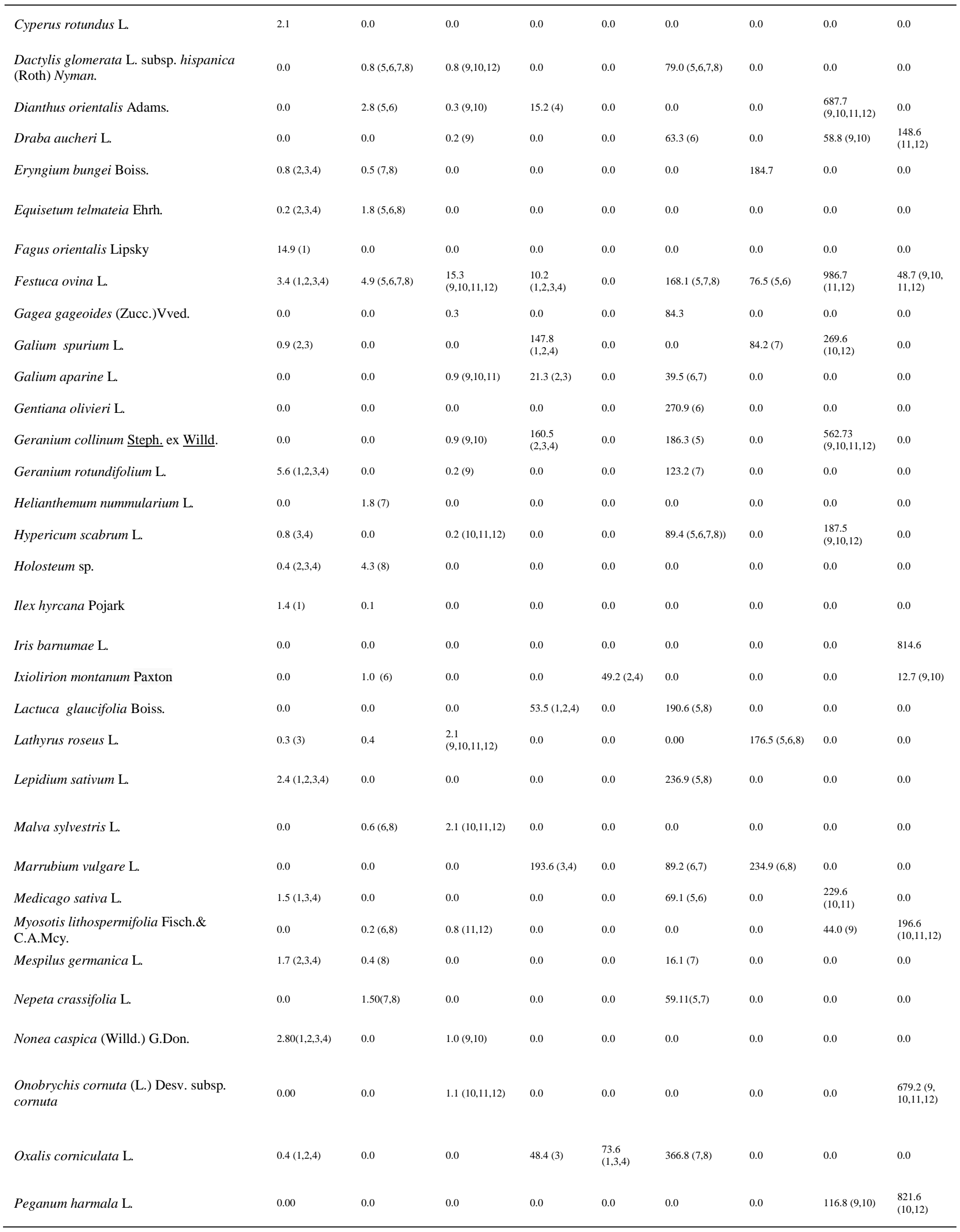




\begin{tabular}{|c|c|c|c|c|c|c|c|c|c|}
\hline Prunella grandiflora $\mathrm{L}$. & 0.0 & 0.0 & 0.0 & $127.4(2,4)$ & 0.0 & 0.0 & $648.8(6,7,8)$ & 0.0 & 0.0 \\
\hline Phleum iranicum $\underline{\text { Bornm } \& \text { Gauba. }}$ & 0.0 & 0.0 & 0.0 & $\begin{array}{l}101.9 \\
(1,2,3,4)\end{array}$ & $\begin{array}{l}53.6 \\
(1,2,3,4)\end{array}$ & $112.9(8)$ & 0.0 & 0.0 & $118.4(10)$ \\
\hline Phlomis olivieri Benth. & $0.4(1,2,3,4)$ & 0.0 & 0.0 & 0.0 & $\begin{array}{l}38.4 \\
(2,3,4)\end{array}$ & $68.5(5)$ & 0.0 & 0.0 & 0.0 \\
\hline Plantago major L. & 0.0 & 0.0 & $5.3(10,12)$ & 0.0 & 0.0 & $179.3(6,7,8)$ & $\begin{array}{l}416.9 \\
(5,6,7,8)\end{array}$ & 0.0 & $\begin{array}{l}473.3 \\
(11,12)\end{array}$ \\
\hline Plantago minor $\mathrm{L}$. & 0.0 & $1.4(5,6,7,8)$ & $0.5(9,10)$ & 0.0 & 0.0 & 0.0 & 0.0 & $\begin{array}{l}165.6 \\
(10,11,12)\end{array}$ & 0.0 \\
\hline Plantago lanceolata $\mathrm{L}$. & $5.5(1,2,3,4)$ & 0.0 & 0.0 & 0.0 & 0.0 & 0.0 & $291.5(5)$ & 0.0 & 0.0 \\
\hline Poa bulbosa $\mathrm{L}$. & 0.0 & $1.2(5,7)$ & $\begin{array}{l}4.6 \\
(9,10,11,12)\end{array}$ & 0.0 & $\begin{array}{l}74.8 \\
(1,3,4)\end{array}$ & 0.0 & $124.5(6,7)$ & $\begin{array}{l}597.7 \\
(10,11,12)\end{array}$ & 0.0 \\
\hline Poa mazandarana $\mathrm{L}$. & $3.0(4)$ & 0.0 & $0.4(10)$ & 0.0 & 0.0 & $23.1(6)$ & $571.1(6,7,8)$ & 0.0 & 0.0 \\
\hline Poa pratensis L. & $0.9(1,4)$ & $2.0(6,8)$ & $1.1(9,10,11)$ & $\begin{array}{l}313.3 \\
(1,2,3,4)\end{array}$ & 0.0 & $148.4(5)$ & 0.0 & 0.0 & $\begin{array}{l}164.9 \\
(11,12)\end{array}$ \\
\hline Polygonum aviculare $\mathrm{L}$. & 0.0 & $1.3(6,7,8)$ & $0.3(10,11)$ & 0.0 & 0.0 & 0.0 & 0.0 & $210.5(9,12)$ & $\begin{array}{l}100.3 \\
(10,11)\end{array}$ \\
\hline Polygonum multiflorum $\mathrm{L}$. & $0.3(1,2)$ & 0.0 & 0.0 & 0.0 & 0.0 & 0.0 & 0.0 & $\begin{array}{l}315.3 \\
(10,12)\end{array}$ & 0.0 \\
\hline Potentilla lignosa $\mathrm{L}$. & 0.0 & $0.8(5,6,7,8)$ & $\begin{array}{l}2.0 \\
(9,10,11,12)\end{array}$ & 0.0 & 0.0 & $173.24(5,8)$ & 0.0 & 0.00 & $\begin{array}{l}548.17(9,1 \\
0,11,12)\end{array}$ \\
\hline Potentilla reptans $\mathrm{L}$. & $1.4(1,2,3,4)$ & 0.0 & $2.2(9,10,11)$ & 0.0 & 0.0 & $298.7(7,8)$ & $37.2(5)$ & $\begin{array}{l}690.9 \\
(9,11,12)\end{array}$ & $\begin{array}{l}148.5 \\
(10,11)\end{array}$ \\
\hline Prunella vulgaris L. & 0.0 & 0.0 & $0.1(11,12)$ & 0.0 & $32.9(1,2)$ & 0.0 & $174.6(5,6)$ & $\begin{array}{l}286 .( \\
(10,11)\end{array}$ & 0.0 \\
\hline Prunus domestica L. & $1.2(1,2,3,4)$ & $0.9(5,6,7,8)$ & 0.0 & 0.0 & 0.0 & 0.0 & 0.0 & 0.0 & 0.0 \\
\hline Prunus spinosa $\mathrm{L}$. & $1.8(1,4)$ & $0.8(5,6,7,8)$ & 0.0 & 0.0 & 0.0 & 0.0 & 0.0 & 0.0 & 0.0 \\
\hline Quercus castaneifolia C.A.Mey & $3.3(1)$ & 0.0 & 0.0 & 0.0 & 0.0 & 0.0 & 0.0 & 0.0 & 0.0 \\
\hline Ranunculus ficaria willd. L. & 0.0 & $3.0(5,6,7,8)$ & $0.5(10)$ & 0.0 & 0.0 & 0.0 & 0.0 & $54 . /(10)$ & 0.0 \\
\hline Ranunculus bulbs L. & $0.7(2)$ & 0.0 & 0.0 & 0.0 & $69.4(1,4)$ & $492.8(5,7)$ & 0.0 & 0.0 & 0.0 \\
\hline Ranunculus repens $\mathrm{L}$. & $0.7(1,2,3,4)$ & $0.9(6,7,8)$ & 0.0 & $214.0(1,3)$ & 0.0 & $93.2(7)$ & $197.7(8)$ & 0.0 & 0.0 \\
\hline Rubus fruticosus $\mathrm{L}$. & 0.8 & 1.7 & 0.0 & 0.0 & 0.0 & 0.0 & 0.0 & 0.0 & 0.0 \\
\hline Salvia hydrangea DC. \& Benth. & $0.1(3)$ & $4.7(6,8)$ & $1.6(10,12)$ & 0.0 & 0.0 & $163.6(6)$ & 0.0 & 0.0 & 0.0 \\
\hline Sonchus sp. L. & 0.0 & 0.0 & 0.0 & 0.0 & 0.0 & 0.0 & $621.3(5,6)$ & $159.3(9,11)$ & 0.0 \\
\hline Sedum hispanicum $\mathrm{L}$. & 0.0 & $0.1(6,7,8)$ & 0.0 & $69.9(2,3,4)$ & 0.0 & $65.3(7)$ & 0.0 & $73.7(10)$ & 0.0 \\
\hline Scutellaria tournifortii Benth. & 0.0 & $1.4(5,6,7,8)$ & 0.0 & $10.3(1)$ & 0.0 & $87.3(8)$ & 0.0 & $\begin{array}{l}129.4 \\
(11,12)\end{array}$ & 0.0 \\
\hline Silene aucheriana Boiss. & $0.2(1,2,3)$ & $0.4(6)$ & $0.3(10,11,12)$ & 0.0 & 0.0 & $100.3(6,7)$ & 0.0 & 0.0 & $\begin{array}{l}731.5 \\
(9,11)\end{array}$ \\
\hline Stachys byzantina Boiss. & $1.0(1,2)$ & $0.1(5,8)$ & $\begin{array}{l}1.2 \\
(9,10,11,12)\end{array}$ & $17.2(2)$ & 0.0 & $146(6,7,8)$ & 0.0 & $\begin{array}{l}318.4 \\
(9,10,11,12)\end{array}$ & $\begin{array}{l}712.8 \\
(10,11,12)\end{array}$ \\
\hline Stachys inflate Benth. & 0.0 & $3.2(5,6,7,8)$ & $0.6(9,10)$ & 0.0 & 0.0 & $196.7(5,6)$ & $137.6(7,8)$ & 0.0 & 0.0 \\
\hline Stachys lavandulifolia $\mathrm{L}$. & 0.0 & 0.0 & 0.0 & 0.0 & 0.0 & $455.6(7,8)$ & 0.0 & $\begin{array}{l}111.5 \\
(9,11,12)\end{array}$ & 0.0 \\
\hline Stellaria media $\mathrm{L}$. & $1.8(1,2,3)$ & 0.0 & $0.3(9,10,11)$ & $56.4(1,4)$ & 0.0 & 0.0 & $176.9(5,7)$ & $67.2(11)$ & 0.0 \\
\hline Sangusorba minor Scop. & $0.1(3)$ & $1.9(5,6,7,8)$ & 0.0 & 0.0 & 0.0 & 0.0 & 0.0 & 0.0 & 0.0 \\
\hline
\end{tabular}




\begin{tabular}{|c|c|c|c|c|c|c|c|c|c|}
\hline Senecio vulgaris $\mathrm{L}$. & $0.2(3)$ & $1.5(5,6,7,8)$ & 0.0 & 0.0 & 0.0 & 0.0 & 0.0 & 0.0 & 0.0 \\
\hline Taraxacum montanum (C. A. Mey.) DC. & 0.0 & $1.6(5,6,7,8)$ & $3.9(9,12)$ & $132.6(2,3)$ & $58.4(2,3)$ & 0.0 & 0.0 & 0.0 & 0.0 \\
\hline Taraxacum officinale LAM. & $3.3(1,2,3,4)$ & 0.0 & 0.0 & 0.0 & 0.0 & $117.2(6)$ & 0.0 & $\begin{array}{l}571.9 \\
(11,12)\end{array}$ & 0.0 \\
\hline Thymus kotschyanus Boiss \& Hohen. & 0.0 & $2.5(8)$ & $3.5(11,12)$ & 0.0 & $46.2(3,4)$ & $76.9(5,6,7,8)$ & 0.0 & $\begin{array}{l}845.3 \\
(9,10,11,12)\end{array}$ & 0.0 \\
\hline Thymus serpyllum $\mathrm{L}$. & 0.0 & 0.0 & $0.4(10,11,12)$ & 98.6 & 0.0 & $153.6(5,6)$ & 0.0 & 0.0 & 0.0 \\
\hline Tragopogon_montana Boiss. & $0.1(1)$ & 0.0 & 0.0 & $112.7(3,4)$ & 0.0 & $26.1(5,8)$ & 0.0 & $\begin{array}{l}193.1 \\
(10,11)\end{array}$ & 0.0 \\
\hline Tragopogon graminifolius DC. & 0.0 & $6.4(5,6,7,8)$ & 0.0 & 0.0 & 0.0 & $168.3(6,7)$ & $415 \cdot 6(6,7)$ & $39.8(9,10)$ & 0.0 \\
\hline Trifolium repens $\mathrm{L}$. & $3.5(1,2,3,4)$ & 0.0 & $1.4(9)$ & 0.0 & 0.0 & $137.8(5,6)$ & 0.0 & 0.0 & 0.0 \\
\hline Urtica dioica $\mathrm{L}$. & $0.5(2,4)$ & $0.6(8)$ & 0.0 & 0.0 & $\begin{array}{l}72.1 \\
(1,3,4)\end{array}$ & $34.7(5,8)$ & 0.0 & $\begin{array}{l}142.5 \\
(10,11)\end{array}$ & 0.0 \\
\hline Veronica capillipes Nevski N. & $0.2(3,4)$ & $1.1(5,6,8)$ & $0.8(10,11)$ & 0.0 & $18.4(3,4)$ & 0.0 & 0.0 & 0.0 & 0.0 \\
\hline Viola occulta Lehm. & $0.1(1)$ & $1.8(5)$ & 0.0 & $284.3(2,4)$ & 0.0 & 0.0 & 0.0 & 0.0 & 0.0 \\
\hline
\end{tabular}


Table 2. Results of GLM when comparing the soil seed bank characteristics among the different altitudes and habitats. Seed density and seed diversity were calculated per $\mathrm{m}^{2}$ and quadrat, respectively. The percentage of similarity between soil seed bank and above-ground vegetation was calculated for each quadrat.

\begin{tabular}{|l|l|l|l|l|}
\hline Factor & Variable & df & F & P-value \\
\hline \multirow{5}{*}{ Density } & habitat & 2 & 16.714 & $<0.01$ \\
\cline { 2 - 5 } & depth & 1 & 90.558 & $<0.01$ \\
\cline { 2 - 5 } & habitat * depth & 2 & 16.369 & $<0.01$ \\
\cline { 2 - 5 } & altitude & 11 & 16.527 & $<0.01$ \\
\cline { 2 - 5 } & depth & 1 & 149.472 & $<0.01$ \\
\cline { 2 - 5 } & altitude * depth & 11 & 16.245 & $<0.01$ \\
\hline \multirow{5}{*}{ Siversity } & habitat & 2 & 9.101 & $<0.01$ \\
\cline { 2 - 5 } & depth & 1 & 118.160 & $<0.01$ \\
\cline { 2 - 5 } & habitat * depth & 2 & 1.829 & .039 \\
\cline { 2 - 5 } & altitude & 11 & 7.130 & $<0.01$ \\
\cline { 2 - 5 } & depth & 1 & 177.878 & $<0.01$ \\
\cline { 2 - 5 } & altitude * depth & 11 & 2.179 & .021 \\
\hline & habitat & 2 & 2.727 & .048 \\
\cline { 2 - 5 } & depth & 1 & 29.088 & $<0.01$ \\
\cline { 2 - 5 } & habitat * depth & 2 & 3.908 & .022 \\
\cline { 2 - 5 } & altitude & 11 & 46.001 & .049 \\
\cline { 2 - 5 } & depth & 1 & 1.073 & .002 \\
\cline { 2 - 5 } & altitude * depth & 11 & 2.942 & \\
\hline
\end{tabular}




\section{Figure captions}

Fig. 1. Location of the study area and transects (Alborz mountain chain, Iran). Each habitat contained four transects and each transect contained five quadrats.

Fig 2. Detrended correspondence analysis (DCA) of quadrats according to species composition of above-ground vegetation and soil seed bank in 120 quadrats (each symbole is one quadrat). Fv= above-ground vegetation in forest $\boldsymbol{\Delta}, \mathrm{Fs}_{\mathrm{s}}=$ soil seed bank in forest $\Delta, \mathrm{Ev}=$ above-ground vegetation in ecotone $\square$, Es= seed bank in ecotone $\square, \mathrm{Mv}=$ above-ground vegetation in meadow $\uparrow, M s=$ seed bank in meadow $\diamond$, ev= eigenvalue.

Fig 3. Average species diversity \pm SE of the soil seed bank in the upper soil layer along the altitudinal gradient. Successive small and capital letters indicate significant difference between different altitudes and habitats, respectively.

Fig 4. Variation in the soil seed bank density \pm SE from the upper soil layer at different altitudes. Successive small and capital letters indicate significant difference between different altitudes and habitats, respectively (original data were used).

Fig 5. Variation in the soil seed bank density \pm SE from the deeper soil layer at different altitudes. Successive small and capital letters indicate significant difference between different altitudes and habitats, respectively (original data were used). 
Figure 1.

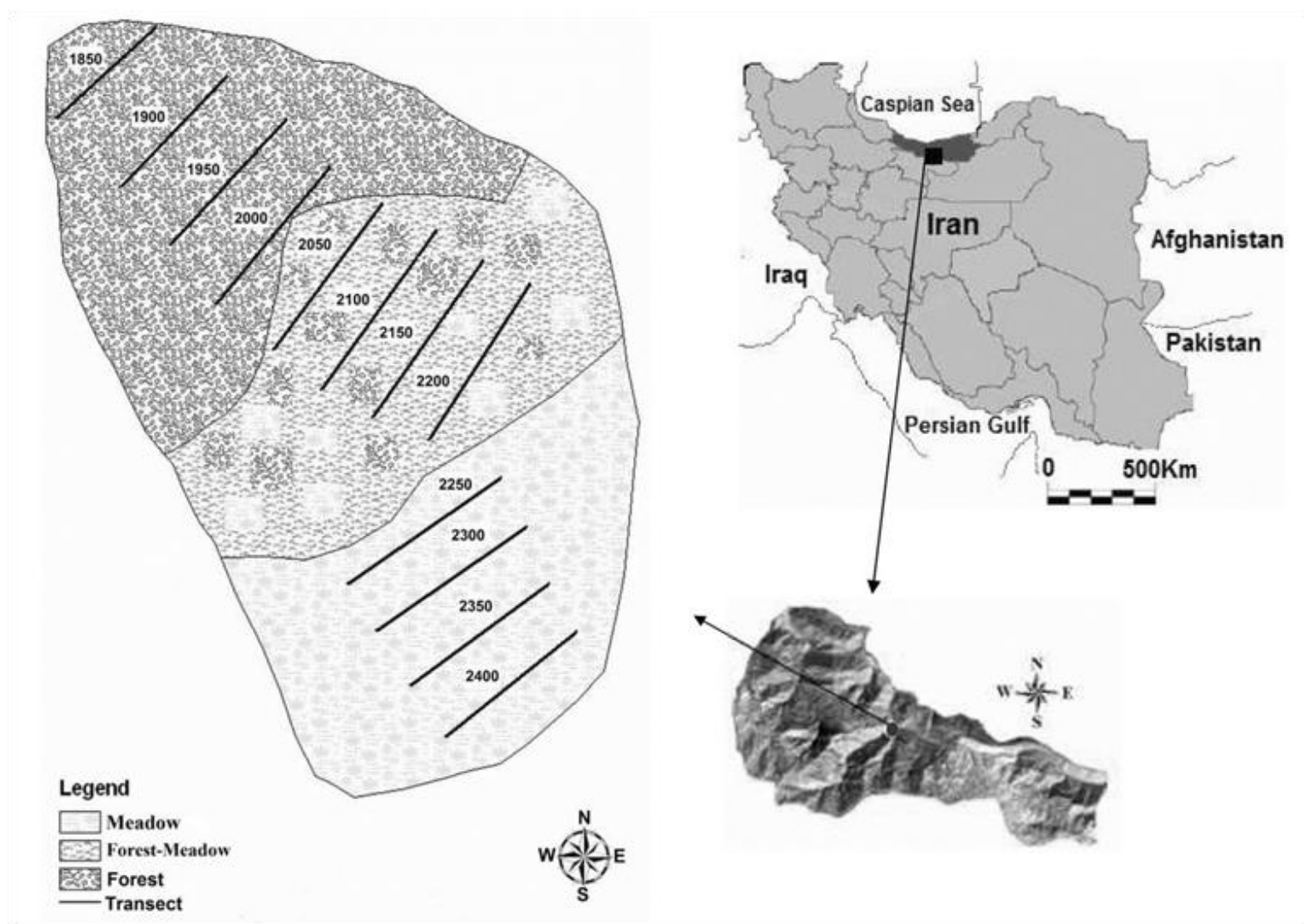

Figure 2. 


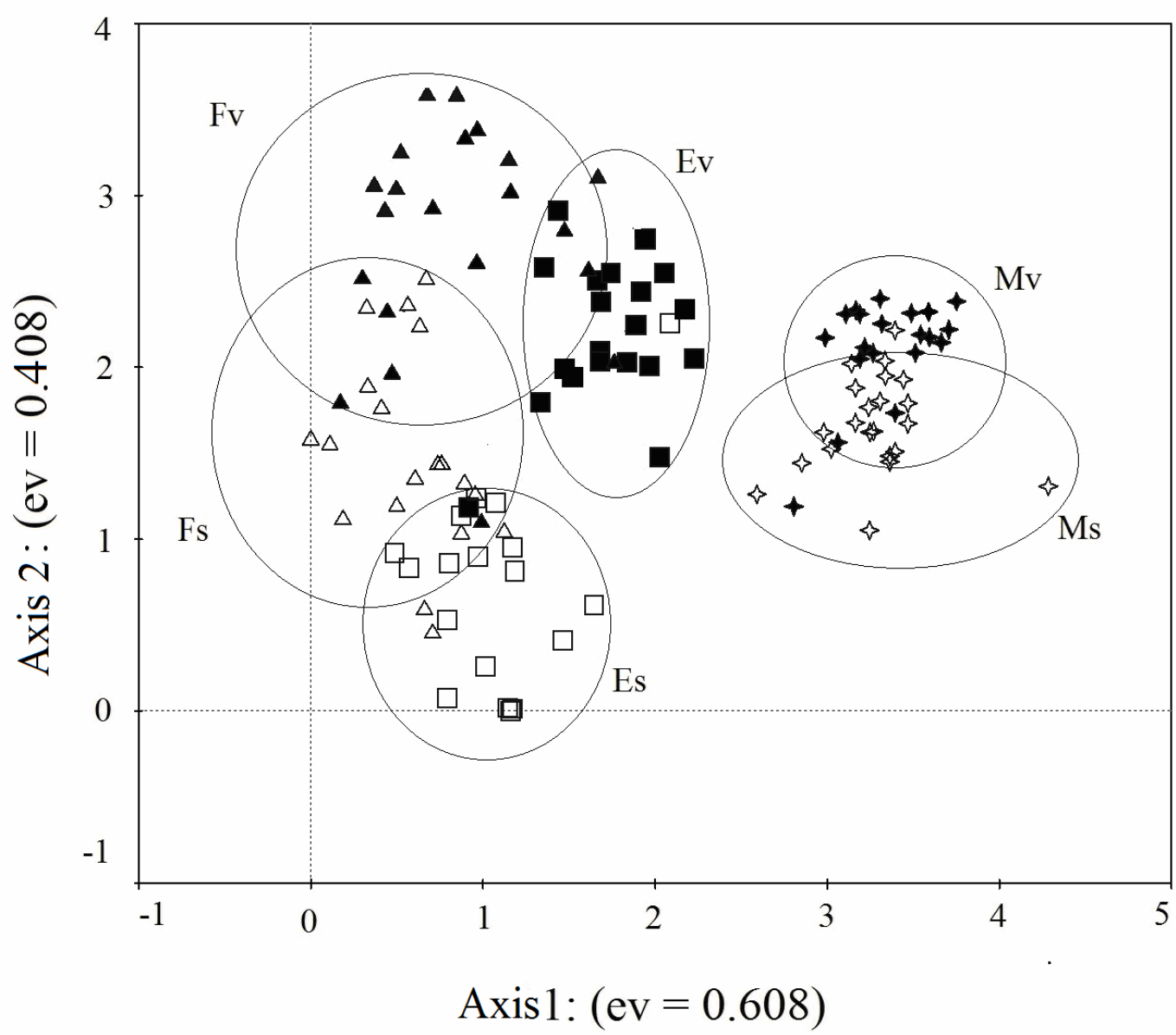

Figure 3 


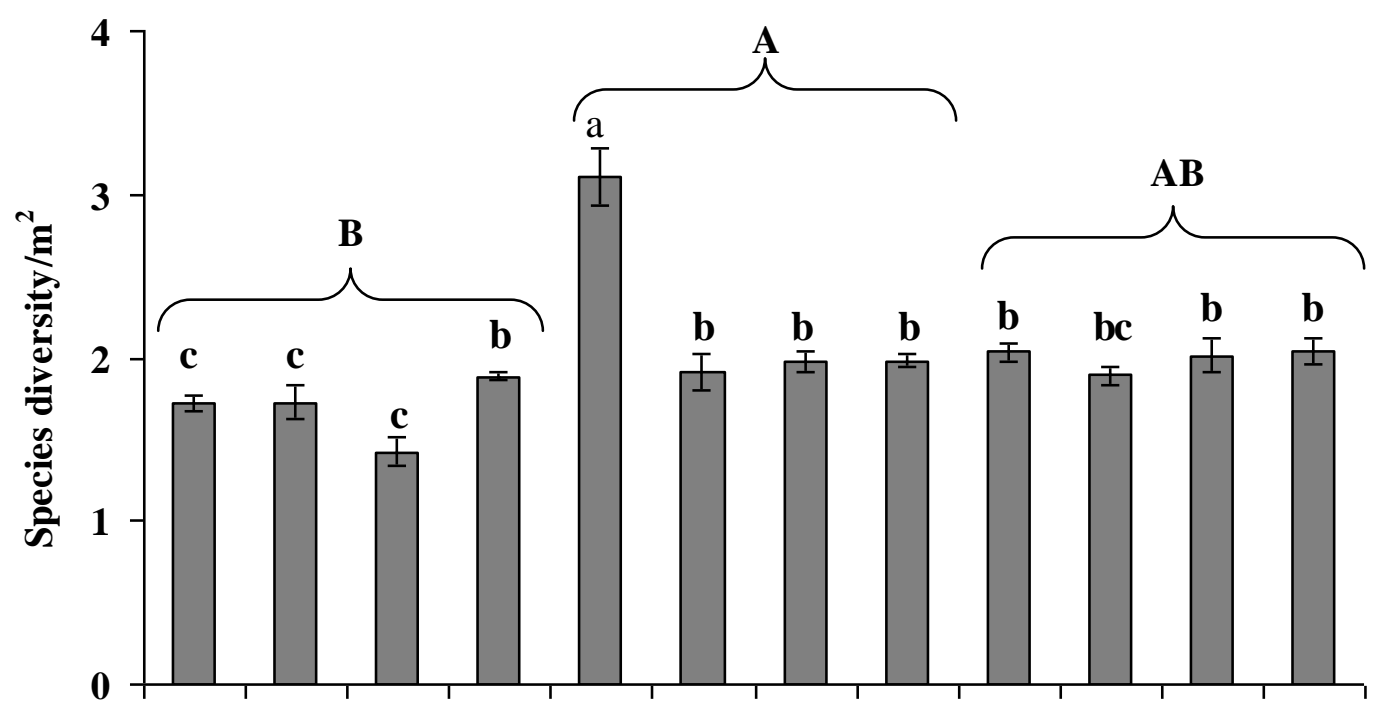

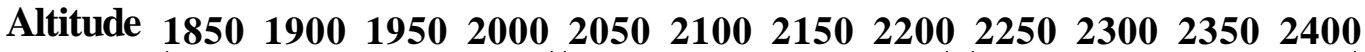

Forest

Ecotone

Meadow 
Figure 4.

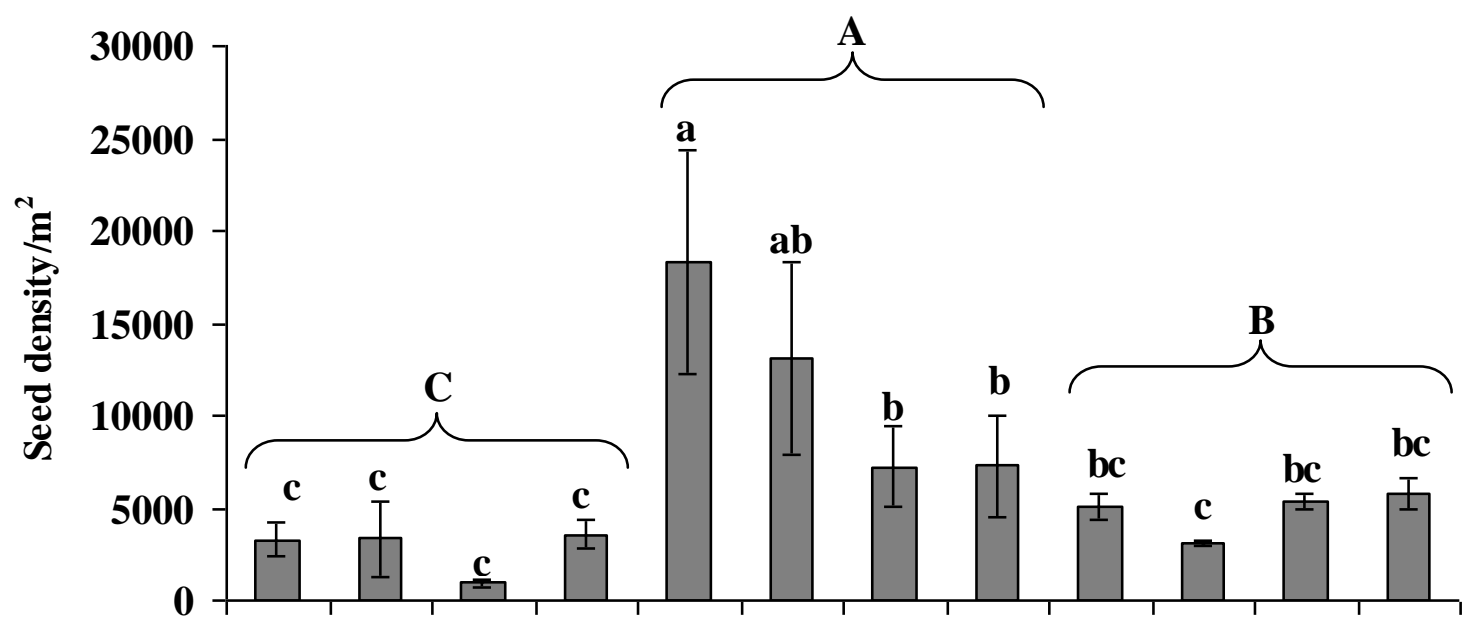

Altitude $1850190019502000,2050210021502200,2250230023502400$, 
Figure 5.

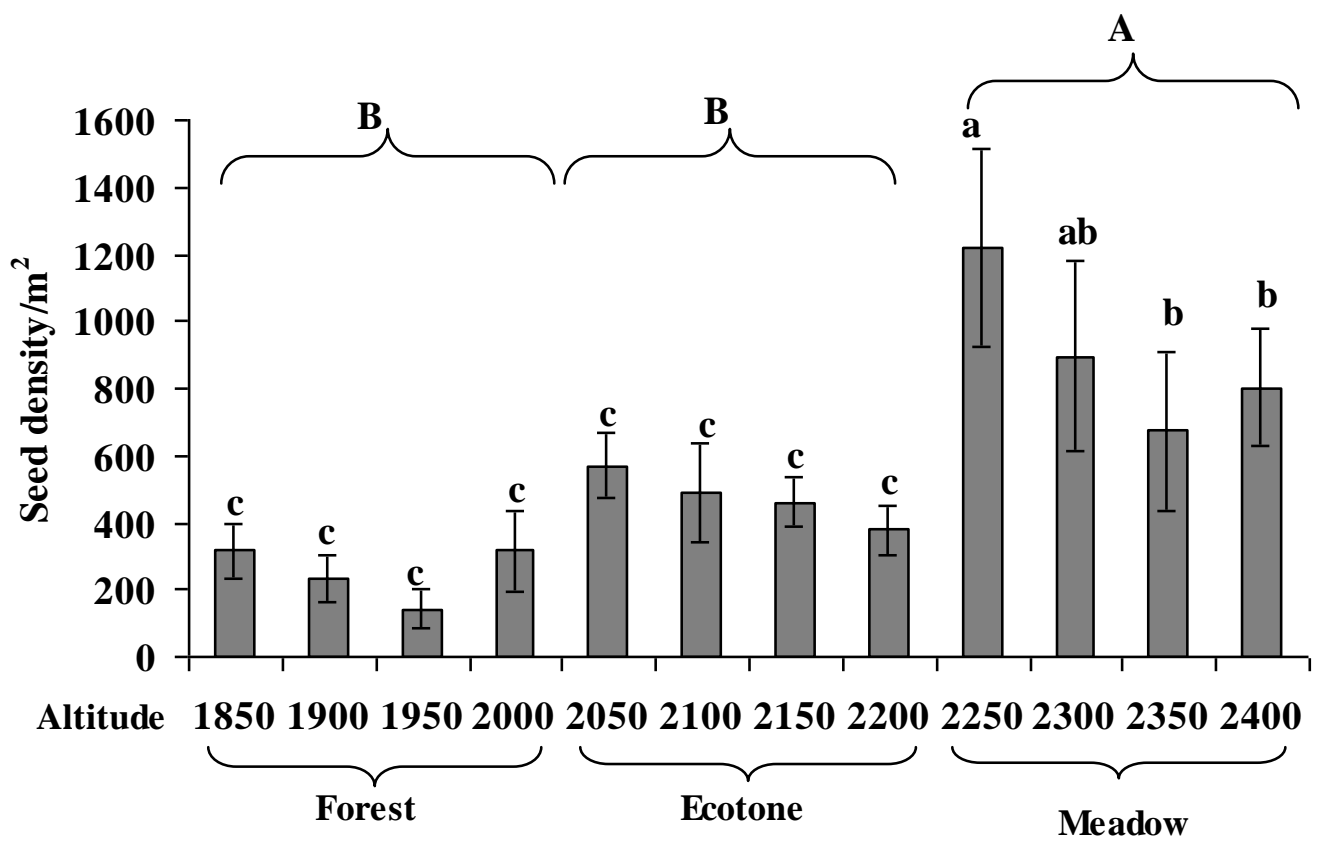

